\title{
The Creation of Fetal Rights: Conflicts with Women's Constitutional Rights to Liberty, Privacy, and Equal Protection
}

\author{
Dawn E. Johnsen
}

Our legal system historically has treated the fetus as part of the woman bearing it and has afforded it no rights as an entity separate from her. A few exceptions to this general rule have been created where necessary to protect the interests of born individuals. In recent years, however, courts and state legislatures have increasingly granted fetuses rights traditionally enjoyed by persons. Some of these recent "fetal rights" differ radically from the initial legal recognition of the fetus in that they view the fetus as an entity independent from the pregnant woman with interests that are potentially hostile to hers. In 'extreme cases, the state has curtailed the autonomy of women during pregnancy to further what were perceived as adverse fetal interests. For example, women have been compelled to submit to surgery in the form of cesarean sections although they preferred to deliver their children through vaginal childbirth. Similarly, a state court has held that a child may sue her or his mother for injuries resulting from the woman's actions during pregnancy.

The social determination of how the legal system should view the fetus should be informed by a careful consideration of all potential implications. ${ }^{1}$ Although the desire to provide legal protection to the fetus often

1. This decision is a social one, not dictated by biology. A scientific inquiry reveals only that the fetus is a living entity, as are the egg and the sperm that combine to form the fetus, which has the potential to develop into a recognizable person given approximately nine months of nurturing in the woman's womb. The legal status that society chooses to confer upon the fetus is dependent upon the goals being pursued and the effect of such status on competing values. In the course of defining the word "alive," Professor Arthur Leff offered an insightful and concise discussion of the relevant considerations in determining under what circumstances the fetus should be considered a legal person:

Important to all these legal problems is the recognition that they are legal (and ethical) problems, dependent not on any deceptively 'natural' biological definition of life, but on social and legal decisions. In 'nature,' things just are; only people classify. . . . [T] The relevant legal question ought not to be whether a foetus is 'alive' or 'a person' from the moment of conception, or the moment of viability, etc., as if the question were one of natural rather than social decision. A legal decision will still have to be made to whom the law ought to give protection and at what cost, paid by who[m] .... Leff, The Leff Dictionary of Law: A Fragment, 94 YALE L.J. 1855, 1997 (1985) (emphasis in
original).

See also Grobstein, A Biological Perspective on the Origin of Human Life and Personhood, in Defining Human Life: Medical, Legal, and Ethical Implications 3, 10-11 (M. Shaw \& A. E. Doudera eds. 1983) [hereinafter cited as Defining Human LIFE] ("[S] uch matters as social status, 
reflects a number of important concerns, the recent expansion of fetal rights has not been accompanied by careful consideration of how best to address those concerns. Most ominously, this expansion has ignored the far-reaching implications for women as the bearers of fetuses.

By creating an adversarial relationship between the woman and her fetus, the state provides itself with a powerful means for controlling women's behavior during pregnancy, thereby threatening women's fundamental rights. A woman's right to bodily autonomy in matters concerning reproduction is protected by the constitutional guarantees of liberty and privacy. Furthermore, the Fourteenth Amendment guarantee of equal protection of the laws should be interpreted to prohibit the state from using women's reproductive capability to their detriment. Any legal recognition of the fetus should be scrutinized to ensure that it does not infringe on women's constitutionally protected interests in liberty and equality during pregnancy.

\section{The Development of Fetal Rights}

\section{A. Unified Interests: Fetal Rights Contingent Upon Live Birth and Against Third Parties}

Until recently, the law did not recognize the existence of the fetus except for a few very specific purposes. As the Supreme Court stated in 1973 in Roe $v$. Wade, "the unborn have never been recognized in the law

\footnotetext{
rights, and obligations associated with personhood move outside the particular concerns of science and become aspects of social structure and policy, subject to the dynamics of value and legal systems, rational discourse, and political determination."); Wikler, Concepts of Personhood: A Philosophical Perspective, in Defining Human Life, supra, at 12,16 (resolution passed by National Academy of Science states that point at which life begins is "a question to which science can provide no answer"). Legal personhood is a status conferred by the courts or by a legislature and differs greatly from our everyday sense of what personhood signifies. For example, the Supreme Court has held that corporations are "persons" for some legal purposes. E.g., Santa Clara County v. Southern Pac. Ry., 118 U.S. 394 (1886) (corporations protected as legal persons by Fourteenth Amendment). Recognition of these rights is not the result of "some theory that ensoulment occurs at the moment of incorporation" or of the corporation's "startlingly human form." Baron, The Concept of Person in the Law, in DEFINING HUMAN LIFE, supra, at 121, 125. Rather, justice to the persons connected with the corporation was thought to require a recognition of the corporation as a legal person. Absent such compelling need, however, the Court has denied the corporation status as a legal person. E.g., Bellis v. United States, 417 U.S. 85 (1974) (privilege against compulsory self-incrimination limited to natural persons). The considerations relevant for the question of whether to create fetal personhood obviously are very different from those for corporate personhood; yet in both contexts legal status should be a "function of the different social policies being advanced by different areas of the law." Id. at 128.

2. 410 U.S. 113 (1973). The Supreme Court held in Roe that a fetus, even when viable, is not a person under the Fourteenth Amendment. Id. at 158. It held further that a woman's right to choose, in consultation with her physician, whether or not to terminate her pregnancy is protected by the constitutional right to privacy. Id. at 152-53. Although the Court found that the state has a compelling interest in the "potentiality of human life" of the fetus after it reaches viability, it concluded that this interest could not justify prohibiting an abortion even after the point of viability if the abortion is necessary to preserve the life or health of the woman. Id. at 162-63.
} 
as persons in the whole sense,"3 and the law has been reluctant to afford any legal rights to fetuses "except in narrowly defined situations and except when the rights are contingent upon live birth." The limited contexts in which courts first recognized the fetus involved rights that were granted to children. These rights of children were unique in that they required acknowledging a child's prior existence as a fetus in her or his mother's womb. Yet because they contained a live birth requirement, these narrow exceptions were consistent with the prevailing view of the fetus as part of the woman. The fetus was not given any rights independent of its mother; rather, it was only after the fetus became a person at birth that it acquired legal rights as a separate entity.

One of these first instances of legal recognition of the fetus involved the right of inheritance. ${ }^{b}$ Where a fetus existed at the time of death of the testator, the fetus was granted the status of a person for the limited purposes of the inheritance, provided that it was subsequently born alive. Fetuses were vested with inheritance rights contingent upon live birth in recognition of parents' presumed desire to provide for children conceived but not yet born at the time of their death. ${ }^{6}$

In another relatively early example of fetal recognition, tort law began looking to the period prior to birth in order to allow a cause of action for prenatal injuries. Before 1946, courts refused to recognize tort claims brought by children for injuries inflicted prior to birth. ${ }^{7}$ Today, however, virtually all American jurisdictions allow tort claims for prenatal injuries if the child is subsequently born alive. ${ }^{8}$ The purpose of tort law is to provide compensation to victims of tortious conduct and, to a lesser extent,

3. Id. at 162 .

4. Id. at 161 .

5. See, e.g., Cowles v. Cowles, 56 Conn. 240, 13 A. 414 (1887); Medlock v. Brown, 163 Ga. 520, 136 S.E. 551 (1927); McLain v. Howald, 120 Mich. 274, 79 N.W. 182 (1899); see also Uniform Probate Code $\$ 2-108$ (1969) ("Relatives of the decedent conceived before his death but born thereafter inherit as if they had been born in the lifetime of the decedent.").

6. See Christian v. Carter, 193 N.C. 537, 538, 137 S.E. 596, 597 (1927) (recognition of fetuses "apparently was based upon the presumed oversight or inadvertence of the parent in providing for an existing or a contingent situation"); see also Baron, The Concept of Person in the Law, in DEFINING HUMAN LiFE, supra note 1, at 128 ("Prime among the goals of the laws of inheritance is fulfillment of the presumed intentions of the testator.").

This recognition of the fetus has been the exception rather than the rule, even for property law. See, e.g., In re Peabody, 5 N.Y.2d 541, 158 N.E.2d 841, 186 N.Y.S.2d 265 (1959) (holding fetus not a person for purposes of $\S 23$ of New York Personal Property Law and distinguishing distinctive purposes served by "fiction" of considering fetus subsequently born alive a person for certain matters of property and tort law).

7. Bonbrest v. Kotz, 65 F. Supp. 138 (D.D.C. 1946) (first case recognizing cause of action by child for injuries received in utero after viability). For an example of the law prior to Bonbrest, see Dietrich v. Northampton, 138 Mass. 14 (1884) (no cause of action for prenatal injuries).

8. W. P. Keeton, D. Dobbs, R. Keeton \& D. Owen, Prosser and Keeton on the Law of TORTS $\S 55$, at 368 (5th ed. 1984) [hereinafter cited as Prosser \& KEETON]. 
to deter such harmful acts. ${ }^{9}$ It is consistent with these purposes to allow a child to recover against third parties for afflictions she or he presently suffers as a result of tortious conduct inflicted on the pregnant woman. In recognizing born plaintiffs' rights to sue for injuries suffered prenatally, tort law provides a means of compensating children and their parents. ${ }^{10}$

The law of fetal rights in its first phase thus did not afford rights to the fetus qua fetus. It did not conceive of the fetus as separate from the woman, but took legal cognizance of the fact that the woman was pregnant. Recognition of the existence of the fetus as part of the pregnant woman was necessary in these instances to protect the interests of born persons, both the subsequently born child and her or his parents. This recognition created no conflicts with the interests of pregnant women.

\section{B. The Creation of Independent Interests: The Recent Expansion of Fe- tal Rights}

\section{Erosion of Live Birth Requirement}

Since the Roe decision, the law increasingly has recognized the fetus in contexts that are not contingent upon subsequent live birth. A majority of states now consider fetuses that have died in utero to be "persons" under wrongful death statutes. ${ }^{11}$ Similar developments have occurred in criminal law. According to traditional common law, the destruction of a fetus in utero is not a homicide; the alleged victim must have been "born alive."12 The Supreme Judicial Court of Massachusetts recently became the first American court to break with this long line of precedent. It held that a fetus was a person for purposes of the Massachusetts vehicular homicide statute, and thus a potential homicide victim. ${ }^{13}$ In addition, a number of states have adopted legislation imposing criminal sanctions for the destruction of a fetus that are identical to those imposed for the murder of a person. ${ }^{14}$

9. Id. at $\S 4$.

10. See Note, Live Birth: A Condition Precedent to Recognition of Rights, 4 Horstra L. Rev. 805,825 (1976) ("The intention in granting recovery in cases of [prenatal injury] is . . . to compensate the postnatal child for the affliction it must bear. Recovery is not, therefore, a recognition that the prenatal child has legal rights.").

11. See Prosser \& KEeton, supra note 8, at 370 \& n.32 (listing states); Mone v. Greyhound Lines, 368 Mass. 354, 331 N.E.2d 916 (1975) (same); see also infra notes 15-17.

12. See Commonwealth v. Cass, 467 N.E.2d 1324, 1328 (1984) ("Since at least the fourteenth century, the common law has been that the destruction of a fetus in utero is not a homicide. . . . The rule has been accepted as the established common law in every American jurisdiction that has considered the question.").

13. Id.

14. See, e.g., CAL. PENal CODE $\S 187$ (West Supp. 1986) ("Murder is the unlawful killing of a human being, or a fetus, with malice aforethought."); IlL. ANN. STAT. ch. 38, § 9-1.1 (Smith-Hurd Supp. 1985); Iowa CoDE ANN. $\S 707.7$ (West 1979); Mich. CoMp. LAws ANN. $\$ 750.322$ (West 1968); Miss. Code ANN. § 97-3-37 (1973); N.H. Rev. Stat. AnN. § 585:13 (1974); OkLa. Stat. 


\section{Women's Rights/Fetal Rights}

The creation of fetal rights not contingent upon subsequent live birth reflects a legitimate desire to protect the rights of the pregnant woman and the expectant father. Recognizing fetuses in wrongful death actions serves to compensate parents for the loss of their expected child and to protect the interests of a woman who has chosen to carry her pregnancy to term. ${ }^{15}$ Such recognition also seeks to deter and punish the tortious conduct. ${ }^{16}$ Similarly, feticide laws use the criminal law to protect pregnant women from physical attack and from the harm of having their pregnancies involuntarily and violently terminated by third parties. Holding third parties responsible for the negligent or criminal destruction of fetuses is therefore consistent with, and even enhances, the protection of pregnant women's interests.

Yet the form that this legal recognition often takes creates the potential for the future expansion of fetal rights in ways that conflict with women's interests. By sometimes identifying the fetus rather than the woman as the locus of the right when there is no live birth, recent laws have reflected a dangerous conceptual move. ${ }^{17}$ The law no longer recognizes the fetus only

AnN. tit. 21, $\$ 713$ (West 1983); UTAh Code ANN. $§ 76-5-201$ (Supp. 1983); Wash. Rev. Code ANN. \$ 9A.32.060 (1977); WIS. STAT. ANN. § 940.04 (West 1982).

15. As noted by Prosser and Keeton, women traditionally have been allowed to recover damages "for their own injuries caused by miscarriage," but not "for the loss of the child." PROSSER \& KEETON, supra note 8, at 369 n.30. The Supreme Court has described wrongful death actions for the destruction of a fetus as filling this gap and providing compensation for the loss of a child:

In a recent development, generally opposed by the commentators, some states permit the par-

ents of a stillborn child to maintain an action for wrongful death because of prenatal injuries.

Such an action, however, would appear to be one to vindicate the parents' interest and is thus

consistent with the view that the fetus, at most, represents only the potentiality of life.

Roe v. Wade, 410 U.S. 113, 162 (1973).

A number of state courts have recognized wrongful death actions for the destruction of fetuses for the explicit purpose of compensating parents. E.g., Volk v. Baldazo, 103 Idaho 570, 574, 651 P.2d 11, 15 (1982) ("It is clear, therefore, that [the wrongful death statute] confers upon parents a cause of action for the wrongful death of a 'child' and thus protects the rights and interests of the parents, and not those of the decedent child."); Dunn v. Rose Way, Inc., 333 N.W.2d 830, 832-33 (Iowa 1983) (distinguishing between claim by estate of fetus under state's survival statute under which "the wrong is done to the injured person and to that person's estate," and claim by parents for loss of fetus under wrongful death statute under which "the wrong is done to a child's parents," and concluding, "[w]hat is involved here is a right of recovery given to a parent. The parent's loss does not depend on the legal status of the child...").

16. E.g., Eich v. Town of Gulf Shores, 293 Ala. 95, 99, 300 So.2d 354, 357 (1974) (allowing suit for wrongful death of fetus "because the punitive nature of our wrongful death statute demands the punishment of the tortfeasor"); Vaillancourt v. Medical Center Hosp., 139 Vt. 138, 142-43, 425 A.2d 92,95 (1980) ("Under such a rule, there is the absurd result that the greater the harm, the better the chance of immunity, and the tort-feaser could foreclose his own liability.").

17. E.g., Eich, 293 Ala. at 99, 300 So.2d at 357 (citing "state's interest and general obligation to protect life"); Danos v. St. Pierre, 402 So.2d 633, 639 (La. 1981) (citing legislative pronouncement that "a human being exists from the moment of fertilization and implantation); Amadio v. Levin, No. 106, slip op. at J-15-9 (Pa. Dec. 4, 1985) ("This Court's former view that the real objective of these lawsuits was to compensate the parents of their deceased children . . . is not only incorrect, but if accepted, merely perpetuates the notion that a child is inseparable from its mother while en ventre sa mere."); Vaillancourt, 139 Vt. at 142, 425 A.2d at 94 ("A viable unborn child, is, in fact, biologically speaking, a presently existing person and a living human being . . . ."); Baldwin v. Butcher, $155 \mathrm{~W}$. 
in those cases where it is necessary to protect the interests of the subsequently born child and her or his parents. Rather, the law has conferred rights upon the fetus qua fetus. Conceptualizing the fetus as an entity with legal rights independent of the pregnant woman has made possible the future creation of fetal rights that could be used against the pregnant woman. In some instances, this potential has already been realized.

\section{Fetal Rights Against Pregnant Women}

\section{a. Existing Rights}

In one such case, a Michigan court held that a child could sue his mother for taking tetracycline during her pregnancy, allegedly resulting in the discoloration of the child's teeth. ${ }^{18}$ The court stated that the appropriate standard for liability was that of the "reasonable" pregnant woman. ${ }^{19}$ Another court has suggested that a woman may be sued by her child for not preventing its birth if she had prior knowledge of the probability of its being born "defective."20 In some states, a woman can be deprived of custody of her child even before its birth if the state feels that her actions during pregnancy endanger the fetus. ${ }^{21}$ In Michigan, a state whose laws do not expressly extend to "prenatal abuse," a court held that evidence of a woman's prenatal "abuse" or "neglect" could be considered during proceedings instituted by the state to deprive her of custody of her newborn child. ${ }^{22}$ The court further held that this evidence could be obtained by reviewing the woman's medical records without her consent, records whose confidentiality was protected by both federal and state statutes. California's criminal child abuse statute, which requires a parent "to furnish necessary food, clothing, shelter or medical attendance," extends to fetuses and imposes a criminal penalty of up to one year in jail and a two

Va. 431, 438-39, 184 S.E.2d 428, 432 (1971) (holding fetus is a person for wrongful death statute is "technically correct in view of the fact that 'biologically speaking' such a child is, in fact, a presently existing person, a living human being') (quoting Panagopoulous v. Martin, 295 F. Supp. 220, 226 (S.D. W. Va. 1969)).

18. Grodin v. Grodin, 102 Mich. App. 396, 301 N.W.2d 869 (1980).

19. Id. at 400-02, 301 N.W.2d. at 870-71.

20. The court saw "no sound public policy which should protect those parents from being answerable for the pain, suffering, and misery which they have wrought upon their offspring." Curlender v. Bio-Science Laboratories, 106 Cal. App. 3d 811, 829, 165 Cal. Rptr. 477, 488 (1980) (dictum).

21. See, e.g., N.J. Stat. ANN. § 30:4C-11 (West 1981):

Whenever it shall appear that any child within this State is of such circumstances that his welfare will be endangered unless proper care or custody is provided, an application . . . may be filed ... . seeking that the Bureau of Childrens Services accept and provide such care or custody of such child as the circumstances may require . . . The provisions of this section shall be deemed to include an application on behalf of an unborn child . . . .

22. In re Baby X, 97 Mich. App. 111, 293 N.W.2d 736 (1980) (within twenty-four hours of birth, child began exhibiting signs of drug withdrawal). 
thousand dollar fine. ${ }^{23}$ Perhaps most alarmingly, states have taken direct injunctive action against pregnant women. Courts have seized custody of fetuses (i.e., of pregnant women) in order to enjoin women from taking drugs that are potentially harmful to fetuses. ${ }^{24}$ They have ordered women to submit to blood transfusions to benefit the fetus, ${ }^{25}$ and have even compelled women against their wishes to undergo cesarean sections instead of vaginal delivery. ${ }^{26}$

\section{b. Potential Expansion}

The creation of fetal rights that can be used to the detriment of pregnant women is a very recent phenomenon, and thus far has occurred in only a relatively small number of cases. Yet, absent an increased awareness of the costs to women's autonomy, these rights will almost certainly continue to expand. ${ }^{27}$ Given the fetus's complete physical dependence on

23. Cal. Penal Code $\S 270$ (West Supp. 1986) ("A child conceived but not yet born is to be deemed an existing person insofar as this section is concerned.").

24. See Chicago Trib., Apr. 9, 1984, at 1, col. 4 (reporting Champaign County judge's order designating fetus ward of state as result of "abuse" by its mother in form of her heroin habit); see also Reyes v. State, 75 Cal. App. 3d 214, 141 Cal. Rptr. 912 (1977) (criminal charge brought against woman for endangering fetus by using heroin during pregnancy; court held relevant statute applied only to children, not fetuses); Boston Globe, Apr. 27, 1983, at 8, col. 1 (reporting physician's request for court to order testing of pregnant woman for drug abuse and to take "what steps are necessary to insure the fetus's proper development").

25. Raleigh Fitkin-Paul Morgan Memorial Hosp. v. Anderson, 42 N.J. 421, 201 A.2d 537, cert. denied, 377 U.S. 985 (1964) (woman objected to blood transfusion on religious grounds). This case, however, was decided prior to the Court's establishment of the constitutional right to privacy in reproductive matters. See Griswold v. Connecticut, 381 U.S. 479 (1965); infra note 75 (citing cases).

26. Jefferson v. Griffin Spalding County Hosp., 247 Ga. 86, 274 S.E.2d 457 (1981) (per curiam) (woman objected to surgery on religious grounds); Annas, Forced Cesareans: The Most Unkindest Cut of All, Hastings CENTER REP., June 1982, at 16 (reporting two additional cases in which women were ordered to undergo cesarean sections).

27. Strong forces are currently encouraging this expansion and are not balanced by a consideration of the competing values. Several amendments to the U.S. Constitution have been proposed that would explicitly grant fetuses rights as "persons" under the Constitution. E.g., S.J. Res. 17, 97th Cong., 1st Sess. (1981); H.R.J. Res. 62, 97th Cong,, 1st Sess. (1981) ("Section 1. With respect to the right to life the word 'person' as used in this article and in the fifth and fourteenth articles of amendment to the Constitution of the United States applies to all human beings . . . including their unborn offspring at every stage of their biological development."). Similar statutes have been introduced by which Congress, without amending the Constitution, would attempt to define "person" as including fetuses for purposes of the Fourteenth Amendment. E.g., S. 158, 97th Cong., 1st Sess., 127 Cong. REC. 24,141-42 (1981) ("Section 1. (a) The Congress finds that the life of each human being begins at conception. (b) The Congress further finds that the fourteenth amendment to the Constitution of the United States protects all human beings."). For further examples of this type of legislation, see Westfall, Beyond Abortion: The Potential Reach of a Human Life Amendment, 8 AM. J.L. \& MED. 97, 97-102 (1982); Hyde, The Human Life Bill: Some Issues and Answers, 27 N.Y.L. SCH. L. REv. $1077,1077-78$ (1982). Senator Orrin Hatch has recently proposed an amendment to the Civil Rights Act of 1964 that would extend its coverage to fetuses, thereby providing them with civil rights. S. 522, 99th Cong., 1st Sess., 131 Conc. Rec. S2262-64 (daily ed. Feb. 27, 1985). Statutes creating "fetal personhood" under the law have also been proposed in a number of state legislatures. See, e.g., Memo from Sandra Kurjiaka, ACLU of Arkansas, to Leadership of Pro-Choice Organizations, Emergency Assistance to Defeat the Arkansas Unborn Child Amendment (Aug. 16, 1984) (on file with author).

Furthermore, a number of legal commentators have recently called for an expansion of fetal rights 
and interrelatedness with the body of the woman, virtually every act of the pregnant woman has some effect on the fetus. A woman could be held civilly or criminally liable for fetal injuries caused by accidents resulting from maternal negligence, such as automobile or household accidents. She could also be held liable for any behavior during her pregnancy having potentially adverse effects on her fetus, ${ }^{28}$ including failing to eat properly, ${ }^{29}$ using prescription, nonprescription and illegal drugs, ${ }^{30}$ smoking, ${ }^{31}$ drinking alcohol, ${ }^{32}$ exposing herself to infectious disease ${ }^{33}$ or to workplace

without paying adequate attention to the potential infringements on women's liberty. See, e.g., King, The Juridical Status of the Fetus: A Proposal for Legal Protection of the Unborn, 77 MicH. L. REv. 1647, 1687 (1979) ("There are no serious legal problems to recognizing legal protection of viable fetuses equal to that already afforded newborns."); Parness \& Pritchard, To Be or Not to Be: Protecting the Unborn's Potentiality of Life, 51 U. CiN. L. REv. 257 (1982) (advocating more extensive legal protection of the fetus, including legal rights assertable against woman bearing the fetus); Walker \& Puzder, State Protection of the Unborn After Roe v. Wade: A Legislative Proposal, 13 STETson L. REv. 237, 240-41 (1984) (advocating passage of legislation granting "to unborn children, from the moment of conception, the basic rights, immunities, and protections available to all other persons, subject only to such limitations as are mandated by the Constitution of the United States"); Note, Parental Liability for Prenatal Injury, 14 ColvM. J.L. \& Soc. Pross. 47, 90 (1978) ("The parents' rights to autonomy should be limited when they conflict with the right of the child to be born whole."). Several of the relatively few commentators who have acknowledged that extensive, unprecedented restrictions on women's autonomy would result have nevertheless advocated expanded fetal rights. See, e.g., Shaw, Conditional Prospective Rights of the Fetus, 5 J. LEGAL MED. 63, 67-69 (1984) ("It will take courage to reverse the well-established legal presumption that the mother's rights transcend those of the fetus."); Robertson, Procreative Liberty and the Control of Conception, Pregnancy, and Childbirth, 69 VA. L. REv. 405, 437 (1983) ("Once she decides to forgo abortion and the state chooses to protect the fetus, the woman loses the liberty to act in ways that would adversely affect the fetus."). Members of the medical community have advocated similar proposals. See infra note 46 and accompanying text.

In contrast, however, several commentators have written convincingly of the dangers of an unthinking expansion of fetal rights. See Westfall, supra; Parness, Social Commentary: Values and Legal Personhood, 83 W. VA. L. Rev. 487 (1981); see also infra note 97.

28. The following examples, cited in notes 29-38 and accompanying text, were offered by commentators advocating the imposition of liability or state regulation on pregnant women.

29. Substandard nutrition during pregnancy may result in low birth weight, which causes higher incidence of defects, such as impairment of fetal brain development, and mortality. See Note, supra note 27 , at 73 ("Nutrition is the single most important exogenous influence in the life of the fetus.").

30. For example, cough medicines may cause congenital goiter or skeletal, liver or brain damage; antacids and laxatives may cause kidney and brain damage; quinine and its derivatives may cause deafness; aspirin may cause damage to the nervous system, kidneys and liver; heroin may cause prematurity, deformity or death. See id. at 73-74.

31. Smoking reduces the fetus's oxygen supply, which is correlated with low birth weight, prematurity and perinatal mortality. "Indeed, a single cigarette smoked by a pregnant woman can disrupt the fetus' heartbeat." See id. at 74.

32. Heavy alcohol use may result in fetal alcohol syndrome, which "consists of growth retardation, facial anomalies, mental retardation, and assorted congenital defects affecting other organs." See Shaw, supra note 27 , at 73 . There is some evidence that the fetus may be adversely affected by even very small amounts of alcohol, see id. at 73, and by heavy alcohol use that occurred even prior to pregnancy, see Beal, "Can I Sue Mommy?" An Analysis of a Woman's Tort Liability for Prenatal Injuries to her Child Born Alive, 21 SaN Diego L. Rev. 325, 360-61 (1984).

33. For example, diabetes in the mother may cause cerebral palsy with mental retardation; congenital syphilis may cause blindness, retardation, and birth defects; and genital herpes may cause brain damage. All may cause fetal death. See Shaw, supra note 27, at 67-69. In addition, maternal mumps, scarlet fever, malaria, small pox, chickenpox, measles and rubella all have potential adverse effects on fetal development. See Note, supra note 27 , at 74 n.227. 
hazards, ${ }^{34}$ engaging in immoderate exercise or sexual intercourse, ${ }^{35}$ residing at high altitudes for prolonged periods, ${ }^{36}$ or using a general anesthetic or drugs to induce rapid labor during delivery. ${ }^{37}$ If the current trend in fetal rights continues, pregnant women would live in constant fear that any accident or "error" in judgment could be deemed "unacceptable" and become the basis for a criminal prosecution by the state or a civil suit by a disenchanted husband or relative. ${ }^{38}$

34. Exposure of the pregnant woman to teratogenic substances may result in harm to the fetus, including brain damage, behavioral disturbances, growth retardation, and gross birth defects. According to Dr. Shaw, "Exposure to organic or inorganic compounds in the chemical industry, dry-cleaning establishments, and gasoline stations are particularly suspect." See Shaw, supra note 27, at 70. Employers are excluding fertile women from working near teratogenic chemicals, claiming concern for their own financial or moral liability for causing birth defects. Some women have been faced with the "choice" of losing their jobs or undergoing sterilization. See Westfall, supra note 27, at 121. For an intelligent discussion of the problem of fetal hazards in the workplace as they affect women's employment rights, see Note, Getting Beyond Discrimination: A Regulatory Solution to the Problem of Fetal Hazards in the Workplace, 95 YALE L.J. 577 (1986).

35. Late in a pregnancy, exercise or sexual intercourse may cause premature labor due to trauma. See Note, supra note 27, at $75 \&$ n.234. Furthermore, a study by Dr. Richard Naeye, Chairperson of the Department of Pathology at Pennsylvania State University found that "[a] pregnant woman's engaging in sexual intercourse is more dangerous to the fetus than the combined effects of her use of alcohol and cigarets [sic] . . . due to a bacterial infection known as chorioamnionitis which is apparently transmitted to the womb by semen." Chicago Trib., June 13, 1981, at 22, col. 1.

36. See Note, supra note 27 , at 75.

37. These activities reduce the fetus's oxygen supply, and thus may cause cerebral palsy, epilepsy, lowered intelligence or mental illness. See id. at 75 \& n.236.

38. Were prenatal tort claims against the mother widely recognized, courts would probably hold pregnant women to the standard of a "reasonable pregnant woman." See Grodin v. Grodin, 102 Mich. App. 396, 400-02, 301 N.W.2d 869, 870-71 (1980). The woman would be required to have knowledge of the potential risks of her behavior at least equal to the typical person in the community. If she had superior knowledge, she would have a duty to act according to that higher standard. The converse, however, would not be true: Courts would apply the community standard if she had inferior knowledge. See Beal, supra note 32, at 353-58.

A number of commentators have written approvingly of this development and have encouraged courts to allow such suits. See Note, supra note 27 , at 84 ("Given that the child's right to sue his parents in negligence has already been established in many jurisdictions, no purpose would be served by singling out and denying the proposed cause of action [of a child prenatally injured by parental negligence].") (footnote omitted); Note, Recovery for Prenatal Injuries: The Right of a Child Against Its Mother, 10 Suffolk U.L. REv. 582, 609 (1976) (pregnant woman should be held to standard of gross negligence).

In the course of advocating greatly expanded legal restrictions on the actions of pregnant women, Dr. Shaw describes what might be expected of a "reasonable pregnant woman." Her "prenatal duties" would include "regular prenatal checkups, a balanced diet with vitamin, iron, and calcium supplementation, weight control, and judicious use of medications, tobacco, and caffeine. Alcohol and narcotic use in pregnancy should be avoided entirely." Shaw, supra note 27, at 83. In addition, "[n]egligent exposure to noxious chemicals and drugs, refusal to accept genetic counseling and prenatal diagnosis, refusal to obtain prenatal therapy, or failure to provide a modified diet, could give rise to a cause of action." Id. at 95. In some high-risk cases, Dr. Shaw would find women negligent for not taking affirmative actions to minimize risks to the fetus even before they could possibly have known that they were pregnant. Id. at 83-84. Finally, if a woman gave birth at home using a midwife after a physician strongly recommended hospital delivery, "she could be liable for fetal neglect." Id. at 89.

In the criminal context Dr. Shaw has stated that "health care professionals and others could be required, by properly drawn statutes, to report both potential and actual fetal abuse." Shaw, supra note 27, at 100 (emphasis in original). In Massachusetts, given the holding in Commonwealth v. Cass that a viable fetus is a person for purposes of the state's vehicular homicide statute, a woman whose reckless driving results in the loss of her late pregnancy may be subject to prosecution for homicide. 
In addition to advocating expansion of criminal penalties and tort recovery, commentators have advocated a wide range of new forms of state regulation of pregnant women's behavior. One such suggestion is that public benefits be withheld from pregnant women who refuse to submit to physical examinations or to abstain from drugs or alcohol. ${ }^{38}$ "High risk" parents could be required to undergo genetic or post-conception screening. ${ }^{40}$ Pregnant women could be prohibited from drinking alcohol and required to submit to breathalyzer tests to ensure compliance. ${ }^{11}$ One commentator has even proposed allowing punitive damages against women who intentionally harm their fetuses. ${ }^{42}$

Perhaps the most foreboding aspect of allowing increased state involvement in pregnant women's lives in the name of the fetus is that the state may impose direct injunctive regulation of women's actions. When expanded to cover fetuses, child custody provisions may be used as a basis for seizing custody of the fetus to control the woman's behavior. As noted by one commentator, "[t]he principal difficulty with the state taking custody of a conceived but unborn child is that the mother herself necessarily is taken into custody." ${ }^{3}$ This fact forcefully demonstrates the threat to women's autonomy inherent in the creation of any fetal right that treats the fetus as an entity independent from the woman. Nevertheless, advocates of fetal rights have proposed that the state increasingly take custody of fetuses and, in some cases, civilly commit pregnant women to "protect" their fetuses.4

This threat appears particularly immediate in the area of coerced medical treatment of pregnant women. Women already have been compelled to submit to blood transfusions and cesarean sections against their will, when it was believed to be in the interest of the fetus. ${ }^{45}$ This phenomenon, troubling in its own right, is susceptible to even more dangerous expan-

467 N.E.2d 1324 (1984). It would be difficult to make an exception for the pregnant woman under Cass given its blanket holding that the fetus is a legal person with rights completely independent from those of the woman.

39 Note, Constitutional Limitations on State Intervention in Prenatal Care, 67 VA. L. REv. 1051, 1051-53 (1981).

40. Id.

41. Shaw, supra note 27 , at 74,103 .

42. Id. at 104 .

43. Parness \& Pritchard, supra note 27, at 294.

44. For example, the commentators who observed that taking a fetus into custody would necessarily entail taking a pregnant woman into custody nevertheless strongly advocate doing just that. Id. ("The failure of states to use child custody provisions on a wide scale to compel conduct benefitting the conceived unborn is both perplexing and troubling."); see also Shaw, supra note 27, at 89 ("[A]n alcoholic or an addict could be institutionalized for the specific purpose of protecting the fetus."); Note, supra note 39, at 1051-52 ("A more effective means of preventing prenatal injury [than allowing tort suits against mother for prenatal injuries] would be for states to intervene in prenatal health care by imposing requirements or restrictions on expectant mothers.") (footnote omitted).

45. See supra notes $25-26$ and accompanying text. 
sion given new procedures in fetal therapy and fetal surgery. When fully developed, these procedures, which had promised to enhance women's reproductive freedom, may be used to restrict it. Some in the medical profession advocate compulsory medical treatment, including forced surgery, where it is determined by medical professionals to be in the interest of the fetus. ${ }^{48}$ The threat to women's autonomy is intensified by the fact that fetal therapy is still in the very early stages of development and, as one physician has noted: "Excessive enthusiasm, combined with inexperience, can be dangerous. Eager to learn and refine these procedures, physicians and surgeons may rush ahead."

\section{G. Expansionary Forces}

\section{Careless Lawmaking}

The threat to the autonomy of pregnant women posed by the expansion of fetal rights has been largely unintentional. When making laws that involve fetuses and pregnant women, courts (as well as legislatures) have felt constrained by the existing law as developed for born persons and have considered the granting of fetal rights an all-or-nothing proposition.

46. See, e.g., Leiberman, Mazor, Chaim \& Cohen, The Fetal Right to Live, 53 OrsTerrics \& GXNECOLOCY 515, 517 (1979) ("If . . . the patient does not consent to undergo a given treatment directed to save the fetus, and which involves no undue risk to the patient, the doctor must be legally entitled to warn the patient that she is committing a felony."). Others argue against allowing physicians or the state to interfere with the wishes of the pregnant woman concerning medical treatment, pointing out that if such intrusion were permitted, fetal therapy might "foreclose current options, rather than create new ones." Ruddick \& Wilcox, Operating on the Fetus, HASTINGs CENTER REP., Oct. 1982, at 10, 11. See also Shriner, Maternal Versus Fetal Rights-A Clinical Dilemma, 53 OBSTETRICS \& GynECOLOGY 518, 519 (1979) ("There is no acceptable alternative to requiring the woman's consent to surgery, and the obstetrician's role must remain one of informing, counseling, and persuading . . . . .). For further discussion of the potential conflicts created between the interests of the pregnant woman and the fetus by viewing the fetus as a separate patient, see Lenow, The Fetus as a Patient: Emerging Rights as a Person?, 9 AM. J.L. \& MED. 1, 15-29 (1983); Ryan, Medical Implications of Bestowing Personhood on the Unborn, in Defining Human Life, supra note 1, at 84.

47. Shriner, supra note 46 , at 10 . Even in cases involving well-established medical procedures, decisions about whether and how to proceed should be left to the woman. Because choices about medical treatment necessarily involve a consideration of competing concerns, the law should encourage physicians to disclose fully the potential risks and benefits of the procedure to enable the woman to make an informed choice. Despite the physician's presumed competence to inform the patient of the possible results of the medical treatment, the physician is not capable of making the required value choices for the woman. See Schultz, From Informed Consent to Patient Choice: A New Protected Interest, 95 YALE L.J. 219, 270-72 (1985). Furthermore, the physician's professional opinion is not always definitive. It is significant that in two of the very few reported cases where cesarean sections were ordered against the woman's consent (but never performed), the cesareans were later found to be unnecessary for the health of the fetuses, both of which were born through vaginal delivery without injury. Annas, supra note 26 , at 16 . Similarly, subsequent to a court ordering his client to submit to a blood transfusion, an attorney expressed his belief that the transfusion was not, in fact, medically necessary: "In point of fact an order was made against this woman when there was no serious problem at all. Two young resident doctors imagined that something might happen. A one-pint blood transfusion for an adult person is never justified. It is simply placing her in a state of risk with no correlative value." Letter from Glen How to the National Council on Crime and Delinquency (May 16, 1967), quoted in Lenow, supra note 46, at 20 n.119. 
They have mistakenly viewed their options as being limited to either granting the fetus personhood status without regard to either the context or the parties involved, or denying the very existence of the fetus. It is thus not surprising that these lawmakers have extended the rights of persons to fetuses when faced with instances of clear harm and injustice, such as when an assailant negligently or willfully destroys a fetus through violence to a pregnant woman.

Courts have also employed unnecessarily simplistic reasoning when adopting the other extreme and refusing to recognize the existence of the fetus at all. For example, in denying a wrongful death action by a fetus, one court stated that it was "incongruous" to allow a woman the constitutional right to abort and yet hold a third party liable to the fetus for unintended but merely negligent acts. ${ }^{48}$ Another court denied a child's wrongful life claim against a physician out of fear that allowing it would necessitate holding liable for wrongful life women who had knowledge of probable fetal defects yet chose not to abort. ${ }^{49}$ Similarly, in limiting a feticide statute to the destruction of viable fetuses (where the statute on its face made no such distinction), the California Supreme Court stated: "If destruction of a nonviable fetus were susceptible to classification as the taking of human life and therefore murder, then the mother no more than the father would have the right to take human life."1so

In thus treating the fetus, courts have glossed over crucial differences between fetuses and persons, and have lost sight of the interests that narrow legal recognition of the fetus traditionally has attempted to protect. They have ignored alternatives to equating the fetus with a person that would have more appropriately served their goals. In some cases, they have too quickly applied the legal status of the fetus in one context to entirely new contexts, ${ }^{\text {s1 }}$ and in others they have unnecessarily refused to

48. Wallace v. Wallace, 120 N.H. 675, 679, 421 A.2d 134, 137 (1980); see also Toth v. Goree, 65 Mich. App. 296, 304, 237 N.W.2d 297, 301 (1975) ("There would be an inherent conflict in giving the mother the right to terminate the pregnancy yet holding that an action may be brought on behalf of the same fetus under the wrongful death act.") (footnote omitted).

49. Elliott v. Brown, 361 So.2d 546, 548 (Ala. 1978) (denying claim for wrongful life against physician reasoning that "[i]mplicit, beyond this claim against a physician for faulty advice, is the proposition that a pregnant woman who, duly informed, does not seek an abortion, and all who urge her to see the pregnancy through, are guilty of wrongful injury to the fetus' ") (quoting Gleitman v. Cosgrove, 49 N.J. 22, 63, 227 A.2d 689, 711 (1967) (Weintraub, J., dissenting)).

50. People v. Smith, 59 Cal. App. 3d 751, 757, 129 Cal. Rptr. 498, 502 (1976).

51. In Commonwealth v. Cass, for example, the court relied on a prior decision that a fetus could bring a wrongful death action as the basis for holding that a fetus could be the legal victim of a homicide in the absence of a feticide statute or any evidence of legislative intent to include fetuses under the homicide statute. 467 N.E.2d 1324 (1984). Given the very different goals and effects of tort law and criminal law, and the absence of evidence of legislative intent, this is a particularly weak ground for deviating from the centuries of unwavering adherence by American courts to the born alive rule. See supra text accompanying notes 12-13.

In holding that a viable fetus was a person within the meaning of 42 U.S.C. $\$ 1983$ (1982) (despite the Supreme Court's holding that a fetus is not a person under the Fourteenth Amendment), a federal 
recognize and protect important interests. ${ }^{52}$ Most importantly, the courts have failed to recognize the fundamental differences between a woman deciding to terminate her own pregnancy and a third party intruding upon her body to end that pregnancy against her will.

To the extent that the expansion of fetal rights is the result of inadequate attention to the particular contexts in which those rights are granted, courts and legislatures should take strict care to ensure that the interests of pregnant women are not impaired by enhancing the legal status of the fetus. Given the physical reality of the fetus as part of the pregnant woman, there exists an inherent potential for conflict between the autonomy of pregnant women and any "right" granted the fetus qua fetus. The law should continue to recognize the existence of the fetus insofar as is necessary to protect the interests of the subsequently born child and is consistent with the pregnant woman's interests, as, for example, in suits by children against third parties for prenatal injuries. In their attempt to protect pregnant women from violent criminal or tortious acts, however, lawmakers should structure the laws so that they retain their focus on the primary subject of protection-the pregnant woman. Attempts to deter the destruction of fetuses by third parties against the will of pregnant women should recognize that the actual physical injury is inflicted on and suffered by the pregnant woman and that the fetus is affected only through her. Courts should, in allowing a tort claim for the negligent destruction of a fetus by third party, make clear that recovery is to compensate parents for the loss of their expected and desired child. ${ }^{53}$ Similarly, an assault on a pregnant woman that causes her to lose her pregnancy could be considered a more serious crime than an assault on a nonpregnant person in recognition of the increased harm suffered by the woman and thereby providing the desired added deterrence. ${ }^{54}$

\section{The anti-abortion movement}

Many anti-abortion activists strongly urge an enhanced legal status for the fetus in nonabortion contexts. ${ }^{\mathrm{BS}}$ Some of these activists are motivated

district court relied simply on what it perceived as a general expansion of legal rights to fetuses. Douglas v. Town of Hartford, 542 F. Supp. 1267 (D. Conn. 1982). But see Harman v. Daniels, 525 F. Supp. 798 (W.D. Va. 1981) (on almost identical facts, viable fetus held not a person under $\S$ 1983).

52. See supra notes $48-50$.

53. Compare cases cited supra note 15 with cases cited supra note 17.

54. New Mexico recently became the first state to enact such legislation in a manner that explicitly focuses on protection of the pregnant woman rather than the fetus. If in the course of committing a felony, such as rape or assault, an individual causes a pregnant woman to suffer a miscarriage, that individual is guilty of a third degree felony. The new law stipulates that voluntarily induced abortions are not affected. N.M. STAT. ANN. §30-3-7 (Supp. 1985).

55. For two of the more explicit, but by no means unique, expressions of the anti-abortion effort, 
by a sincere belief that a fetus is the moral equivalent of a born person. Others recognize that greater fetal protection serves to create a general atmosphere that is more hostile to the abortion right. Yet the fetal interests involved in the fetal rights debate differ greatly from those raised by the issue of abortion. In the nonabortion context, the woman intends no injury to the fetus; rather, she seeks to carry her pregnancy to term and is likely to act with the interests of the fetus in mind. In this context, the "state purpose" is not to preserve the life of the fetus against the pregnant woman's will, but to prescribe a woman's behavior during her wanted pregnancy. If the state were to deprive women of their right to choose to have an abortion, it would impose on women a duty to bear unwanted children; by creating fetal rights susceptible to use against pregnant women, the state compels women who desire to bear children to reorganize their lives in accordance with judicially-defined norms of behavior. ${ }^{s B}$

\section{Concern for health of children}

To date the expansion of fetal rights assertable against pregnant women has been largely the product of accident and of zealous and imprecise political forces. Yet some commentators now argue that granting fetuses rights assertable against the women bearing them serves the legitimate, and even important, purpose of protecting the interests of the subsequently born child. ${ }^{87}$ Precisely because the fetus is dependent upon the body of the woman for its continued life, these critics note, the health of the child depends in part on the conduct of the woman during pregnancy. They contend, therefore, that where the acts of a pregnant woman threaten to harm her future child, the state should intervene and dictate pregnant women's behavior.

This argument, too, misconceives the nature of the relationship between the fetus and the pregnant woman and is insensitive to the great harm

see President Reagan's 1985 State of the Union address, in which he stated: "Abortion is either the taking of a human life or it isn't. And if it is-and medical technology is increasingly showing that it is-it must be stopped." Nat'l NOW Times, May 1985, at 5, col. 2; and Illinois's abortion law, in which the legislature sets forth "the longstanding policy of this State, that the unborn child is a human being from the moment of conception" and states that the "longstanding policy of this State to protect the right to life of the unborn child from conception by prohibiting abortion unless necessary to preserve the life of the mother is impermissible only because of the decisions of the United States Supreme Court." Ill. ANN. STAT. ch. 38, § 81-21 (Smith-Hurd Supp. 1985).

56. The potential infringements on women's liberty could actually discourage women from becoming pregnant, and, given certain adverse precedents, could in fact create an incentive for them to abort. For example, a woman with an alcohol or drug problem might abort if faced with the possibility of civil commitment. Alternatively, in order to avoid being "caught" by the authorities, she might not seek any prenatal care, thereby endangering both her own and her future child's health. Extending personhood to fetuses in nonabortion contexts thus threatens not the abortion right, but women's freedom to bear children, and is a particularly inappropriate method for opposing Roe, 410 U.S 113.

57. See supra note 27 . 
that would be inflicted on women by such an interventionist policy. A woman should not behave during pregnancy so as to avoid any risks to the fetus regardless of the costs to her, just as no individual should refrain from all activities that pose any threat to her or his well-being. Rather, the relevant question is what is in the interests of the woman, given that she is pregnant. Allowing the state to control women's actions in the name of fetal rights, however, reflects a view of the fetus as an entity separate from the pregnant woman, with interests that are hostile to her interests. In fact, by granting rights to the fetus assertable against the pregnant woman, and thus depriving the woman of decisionmaking autonomy, the state affirmatively acts to create an adversarial relationship between the woman and the fetus. By separating the interests of the fetus from those of the pregnant woman, and then examining, often post hoc, the effect on the fetus of isolated decisions made by the woman on a daily basis during pregnancy, the state is likely to exaggerate the potential risks to the fetus and undervalue the costs of the loss of autonomy suffered by the woman. ${ }^{58}$

Where the woman has chosen not to exercise her right to abort her fetus, she is likely to care deeply about the well-being of the child she will bear. It is therefore more rational to assume that women will consider potentially harmful effects to their children resulting from their actions during pregnancy than to subject all women to state regulation of their actions during pregnancy. Furthermore, because the decisions a woman makes throughout her pregnancy depend on her individual values and preferences, complicated sets of life circumstances, and uncertain probabilities of daily risk, the woman herself is best situated to make these complex evaluations.

But we should not be concerned merely with whether the state or the woman is better situated to decide how to reconcile fetal and maternal interests. Another fundamental issue is who has the right to make the value choices required to decide such questions. By substituting its judgment for that of the woman, the state deprives women of their right to control their lives during pregnancy-a right to liberty and privacy protected by the Constitution. Furthermore, by regulating women as if their lives were defined solely by their reproductive capacity, the state perpetuates a system of sex discrimination that is based on the biological difference between the sexes, thus depriving women of their constitutional right to the equal protection of the laws. Lawmakers should carefully consider the liberty and equality interests at stake, as well as the value of the state involvement, before imposing intrusive regulations on pregnant women in the name of fetal protection.

58. See infra note 68 . 


\section{Gonstitutional Limitations on Recognition of Fetal RIGHTS}

\section{A. The Fetus and the Constitution}

The Supreme Court has never considered the possible deleterious effects of granting fetal rights in nonabortion contexts on women's exercise of their constitutional rights. In recognizing a woman's right to choose to have an abortion, however, the Court did make a number of relevant observations. ${ }^{59}$ In Roe $v$. Wade, the Court acknowledged that fetuses differ from persons in very basic and legally relevant ways, and that the extension of rights to fetuses reflects an affirmative value choice by the state not compelled by biological fact. ${ }^{60}$ The Gourt rejected the notion that the state could avoid the great complexities involved in determining the legal status of the fetus simply by equating the fetus with a person. In holding that the state could not adopt a concept of the fetus that conflicted with the right of women to terminate their pregnancies, the Court stated: "In view of all this, we do not agree that, by adopting one theory of life, Texas may override the rights of the pregnant woman that are at stake." ${ }^{.61}$

\section{B. Infringements of Women's Liberty and Privacy}

Vesting fetuses with rights that are assertable against the women bearing them would create an unprecedented intrusion on women's bodies and personal lives. The magnitude of the intrusion on women's rights threatened by the current expansion of fetal rights implicates basic constitutional liberty and privacy interests that have been recognized by the Court in Roe and in other cases. The Court has long held that the Constitution protects certain aspects of personal autonomy from state interven-

59. Roe v. Wade, 410 U.S. 113 (1973). Yet the Court's discussion in Roe clearly is not determinative of the constitutionality of fetal rights in nonabortion contexts. The Court did not fully analyze the nature of the relationship between the fetus and the woman, nor did it address the equality concerns raised by restrictions on access to abortion given that only women, and not men, are subject to those restrictions. Furthermore, the factors relevant in determining the legal status of the fetus in nonabortion contexts are significantly different from those considered in Roe. See supra text accompanying notes 55-56; infra note 82. Neither the Supreme Court nor any lower court has fully considered the threat that legal recognition of the fetus poses to women's constitutional rights of liberty and privacy and to the equal protection of the laws.

60. These implications naturally arise from Roe's holding that even a viable fetus is not a person under the Fourteenth Amendment, and are further supported by the Court's discussion of the legal status of the fetus in nonabortion contexts. 410 U.S. at 161-62. See supra text accompanying notes $2-4$.

61. 410 U.S. at 162. In Roe, the Court held that the state's interest in the "potentiality for life" of the fetus becomes compelling after viability and can be used to restrict third trimester abortions that are not necessary to preserve the life or health of the woman. Id. at 163-64. The Court defined a viable fetus as one "potentially able to live outside the mother's womb, albeit with artificial aid." Id. at 160 (citing L. Hellman \& J. Pritchard, Williams Obstetrics 493 (14th ed. 1971)). For further discussion of the viability standard, see infra note 82 . 
tion. The Court has described the "right to be left alone" as "the most comprehensive of rights and the right most valued by civilized man." This right is particularly important when the state intervention involves a physical intrusion on an individual's body: "No right is held more sacred, [n]or is more carefully guarded . . . than the right of every individual to the possession and control of his own person." government control of one's physical person has been described as the right to "personal privacy and dignity," "personal security,""65 and "bodily security and personal privacy."

There have been few attempts at state intrusion of the magnitude and sweeping nature involved in state regulation of pregnant women's actions. ${ }^{67}$ Courts have held unconstitutional even isolated instances of the type of intrusions to which pregnant women would be continually subjected. ${ }^{88}$ For example, the Supreme Court has held that the state may not

62. In an often-quoted dissent in Olmstead v. United States, Justice Brandeis wrote: "The makers of our Constitution undertook to secure conditions favorable to the pursuit of happiness. They recognized the significance of man's spiritual nature, of his feelings and of his intellect. They knew that only a part of the pain, pleasure and satisfactions of life are to be found in material things. They sought to protect Americans in their beliefs, their thoughts, their emotions and their sensations. They conferred, as against the Government, the right to be left alone-the most comprehensive of rights and the right most valued by civilized men." 277 U.S. 438, 478 (1928) (Brandeis, J., dissenting), quoted in Stanley v. Georgia, 394 U.S. 557, 564 (1969) (Constitution prohibits making private possession of obscene matter a crime).

63. Union Pac. Ry. v. Botsford, 141 U.S. 250, 251 (1891) (under common law, court has no power to require plaintiff in tort action to submit to surgical examination for purpose of verifying injuries), quoted in Terry v. Ohio, 392 U.S. 1, 9 (1968). The Court further stated, "The right to one's person may be said to be a right of complete immunity: to be let alone." Union Pac. Ry., 141 U.S. at 251 (citation omitted).

In discussing the scope of the right to "personal security" as protected by the Fourth Amendment's prohibition of unreasonable search and seizure, the Court stated, "We have recently held that "the Fourth Amendment protects people, not places,' and wherever an individual may harbor a reasonable 'expectation of privacy,' he is entitled to be free from unreasonable governmental intrusion." Terry, 392 U.S. at 9 (citations omitted).

64. Schmerber v. California, 384 U.S. 757, 767 (1966) ("The overriding function of the Fourth Amendment is to protect personal privacy and dignity against unwarranted intrusion by the State.").

65. Ingraham v. Wright, 430 U.S. 651, 673 (1977) ("Among the historic liberties so protected [substantively by the Fourteenth Amendment] was a right to be free from, and to obtain judicial relief for, unjustified intrusions on personal security.").

66. Winston v. Lee, 105 S.C.t 1611 (1985), affg 717 F.2d 888 (4th Gir. 1983) (involuntary removal of bullet from suspect unconstitutional; decided on Fourth Amendment grounds, but lower court noted could be decided on Fourteenth Amendment grounds); see also Rochin v. California, 342 U.S. 165 (1952) (forcible pumping of criminal suspect's stomach violates substantive protection of Fourteenth Amendment); Pruneyard Shopping Center v. Robins, 447 U.S. 74, 93-94 (1980) (Marshall, J., concurring) ("The constitutional terms 'life, liberty, and property' . . . have a normative dimension as well, establishing a sphere of private autonomy which government is bound to respect. Quite serious constitutional questions might be raised if a legislature attempted to abolish certain categories of common-law rights in some general way. Indeed, our cases demonstrate that there are limits on governmental authority to abolish 'core' common-law rights . . . .") (footnotes omitted).

67. It is significant that the types of restrictions that would be imposed on pregnant women far exceed any that we as a culture would allow children to impose on parents. For example, we would not compel an individual to move to a different climate if her or his child's health required it and we would not permit a child to sue her or his parents for deciding not to relocate.

68. The privacy and autonomy cases and doctrines discussed herein deal exclusively with regula- 
compel criminal suspects to undergo certain medical procedures, ${ }^{69}$ and a federal circuit court has recognized the right of even involuntarily committed mental patients to refuse medical treatment. ${ }^{70}$ The fact that these pro-

tions that "directly" infringe on protected interests, either by making criminal certain behavior, or by actually forcing the individual to engage in or refrain from specified behavior through the use of the injunctive power of the state. It might be argued that privacy and autonomy rights are not as clearly threatened by a more "indirect" regulation, namely, the threat of post-natal civil liability. This sort of "deterrent" regulation was involved in such cases as the denial of child custody, see supra text accompanying note 22 , and actions for damages against the mother by the child, see supra text accompanying notes 18-20. Though the threat to a woman's autonomy may not be as immediately apparent in post-natal cases as in cases involving criminal sanctions or direct state appropriation of a woman's body, the threat is, nevertheless, just as severe. Fear of liability for damages or of the denial of child custody obviously could have an enormous impact on a woman's behavior.

The potential impact is intensified by the fact that the standards for behavior are not likely to be as clearly delineated as in the more "direct" cases. Women would be at the mercy of an undefined and ever-developing common law. Not only are the standards of the state common law courts constantly changing and often incoherent, but also women would confront varying jury conceptions of "reasonable" behavior. Given common stereotypical public conceptions of the "proper" role of women, particularly pregnant women, there is very little behavior that might not be found by a jury to be "unreasonable." This is particularly a risk when juries are confronted with injuries that will otherwise go unremedied, as is likely often to be true in such cases. It would not, in fact, be "unreasonable" for a pregnant woman, faced with the prospect of post-natal civil liability according to community standards of propriety, to assume that the only safe course of behavior is to lie prone for nine months. Thus, the distinction between "direct" and "indirect" sanctions in the fetal rights context is a distinction without a difference. The actual diminution of women's autonomy to make decisions is just as severe whether the regulation is immediate or merely lurking in some vague threat of future penalties.

69. For example, in Rochin v. California, the Court held that the forcible pumping of a criminal suspect's stomach violated the individual's Fourteenth Amendment due process rights, and was "conduct that shocks the conscience." 342 U.S. 165, 172 (1952). This was true despite the fact that the individual was a criminal suspect; police officers witnessed the suspect swallow two pills, which they believed to be narcotics, in an attempt to hide them from the officers; the stomach pumping involved an isolated instance of intrusion; and the Court stressed that it must review criminal convictions from state courts "with due humility," id. at 168.

In Winston $v$. Lee, the Court held that to remove surgically a bullet from a suspect's body against his will for use as evidence against him would violate his constitutional rights. $105 \mathrm{~S}$. Ct. 1611 (1985). The Court considered "[whether] the community's need for evidence outweighs the substantial privacy interests at stake," id. at 1616-17 and stated "[a] compelled surgical intrusion into an individual's body for evidence. . . implicates expectations of privacy and security of such magnitude that the intrusion may be 'unreasonable' even if likely to produce evidence of a crime," $i d$. at 1616. The Court found the proposed surgery to be an "unreasonable" intrusion even though the risks of general anesthesia were considered "minimal" in this case, id. at $1618 \mathrm{n.7}$, and the Court noted, "whether the surgery is to be characterized in medical terms as 'major' or 'minor' is not controlling," id. at 1618 n.8.

Although the Supreme Court in Schmerber v. California held that the state could compel an individual to take a blood test, the Court stated it could do so only if it could demonstrate that it was necessary to perform the test immediately or else the evidence would be lost, thereby making it impossible to obtain a search warrant. 384 U.S. 757 (1966). The Court stressed, moreover, the very limited application of this case:

It bears repeating, however, that we reach this judgment only on the facts of the present record. The integrity of an individual's person is a cherished value of our society. That we today hold that the Constitution does not forbid the States minor intrusions into an individual's body under stringently limited conditions in no way indicates that it permits more substantial intrusions, or intrusions under other conditions.

Id. at 772 .

70. The Court of Appeals for the Third Circuit has held that the substantive right to refuse medical treatment derives from the constitutional right to liberty and is not extinguished if an individual is committed involuntarily to a mental institution. Rennie v. Klein, 653 F.2d 836 (3d Cir. 1981), vacated on other grounds, 458 U.S. 1119 (1982), on remand, 720 F.2d 266 (3d Cir. 1983) (reaffirm- 
hibited attempts at intrusions have involved those over whom the state traditionally exerts a great deal of authority-criminal defendants and mental patients-suggests the radical nature of the fetal rights trend and its incompatibility with our heritage of civil liberties. ${ }^{71}$ One judge, concurring in an order compelling a pregnant woman to submit to a cesarean section, acknowledged this anomaly: "The power of a court to order a competent adult to submit to surgery is exceedingly limited. Indeed, until this unique case arose, I would have thought such power to be nonexistent." "72

Although this judge suggests that protecting the life of the fetus should represent a unique exception to the state's traditional deference to adults' personal decisions, the law suggests the opposite: The protection against state intrusion afforded by the Constitution is especially strong where issues of childbearing are involved. The Supreme Court, in a long line of cases, has affirmed, as part of the constitutional "right of personal privacy," ${ }^{\prime \prime 3}$ an individual's right to "independence in making certain kinds of important decisions," "74 at "the very heart" of which lie decisions in matters of childbearing. ${ }^{75}$ Because the Court has emphasized that the right of

ing constitutional right to refuse drugs). The court quoted a state court as follows: " [L]iberty includes the freedom to decide about one's own health. This principle need not give way to medical judgment.' " Id. at 847 (quoting In re KKB, 609 P.2d 747, 749 (Ok. 1980)). Even when involuntarily committed, "the patient's liberty is diminished only to the extent necessary to allow for confinement by the state so as to prevent him from being a danger to himself or to others." Id. at 843 .

71. A number of state courts have held that the right to refuse medical treatment as protected by the right to privacy extends to situations where the treatment is necessary to preserve the patient's life. As one court stated, "The constitutional right to privacy, as we conceive it, is an expression of the sanctity of individual free choice and self-determination as fundamental constituents of life. The value of life . . . is lessened . . . by the failure to allow a competent human being the right of choice." Superintendent of Belchertown State School v. Saikewicz, 373 Mass. 728, 742, 370 N.E.2d 417, 426 (1977) (footnote omitted). One court has stated that, even when an individual is mentally incompetent, because the right to refuse medical treatment is a "very personal right to control one's own life," the correct standard to be used in deciding whether to withdraw life-sustaining treatment "is not what a reasonable or average person would have chosen to do under the circumstances but what the particular patient would have done if able to choose for himself." In re Conroy, 98 N.J. 321, 360-61, 486 A.2d 1209, 1229 (1985). See also In re Quinlan, 70 N.J. 10, 355 A.2d 647, cert. denied, 429 U.S. 922 (1976); In re Yetter, 62 Pa. D. \& C.2d 619 (C.P. of Northampton County 1973).

72. Jefferson v. Griffin Spalding County Hosp. Auth., 247 Ga. 86, 89, 274 S.E.2d 457, 460 (1981) (Hill, J., concurring) (per curiam).

73. Carey v. Population Servs. Int'l, 431 U.S. 678, 684 (1977) (right to use contraceptives).

74. Id. (quoting Whalen v. Roe, 429 U.S. 589, 599-600 (1977)).

75. Carey, 431 U.S. at 685. "[T] $]$ he Constitution protects individual decisions in matters of childbearing from unjustified intrusion by the State." Id. at 687. Significantly, the Court has characterized the right to privacy as protecting autonomy in "matters relating to marriage, procreation, contraception, family relationships, and child rearing and education. In these areas, it has been held that there are limitations on the States' power to substantively regulate conduct." Whalen v. Roe, 429 U.S. at 600 n.26 (quoting Paul v. Davis, 424 U.S. 693, 713 (1976)). See, e.g., Skinner v. Oklahoma, 316 U.S. 535 (1942) (right to procreation); Griswold v. Connecticut, 381 U.S. 479 (1965) (right to use contraceptives; applied to married individuals); Loving v. Virginia, 388 U.S. 1 (1967) (right to marry); Eisenstadt v. Baird, 405 U.S. 438 (1972) (right to purchase and use contraceptives; applied to unmarried individuals); Roe v. Wade, 410 U.S. 113 (1973) (right to abortion); Carey v. Population Servs. Int'l, 431 U.S. 678 (1977) (right to purchase and use contraceptives; applied to minors under 
privacy is the right to make decisions free from state intrusion, not only is the state prohibited from infringing directly on the protected right, but it also may not act in any way to interfere with the individual's decisionmaking autonomy. For example, although there is no "independent fundamental 'right of access to contraceptives," "76 state restrictions on access to contraception must be narrowly drawn to serve a compelling state interest, because they infringe on the "exercise of the constitutionally protected right of decision in matters of childbearing . . . . ."77

Just as the state may not force a woman to bear a child against her will, it may not act to penalize her for deciding to bear a child. In Cleveland Board of Education v. LaFleur, ${ }^{78}$ the Court found unconstitutional a rule that required pregnant school teachers to take unpaid maternity leave for the five months prior to an expected childbirth. Noting that "freedom of personal choice in matters of marriage and family life is one of the liberties protected by the Due Process Clause of the Fourteenth Amendment," the Court stated that "[b]y acting to penalize the pregnant teacher for deciding to bear a child, overly restrictive maternity leave regulations can constitute a heavy burden on the exercise of these protected freedoms." ${ }^{\prime 79}$ By creating fetal rights that can be used against the woman bearing the fetus to restrict her conduct, the state appropriates a woman's right to control her actions and imposes a burden at least as great as that imposed in LaFleur.

In determining how great a burden a state regulation imposes on privacy interests, courts often focus on the intrusiveness of the necessary

sixteen years of age); Zablocki v. Redhail, 434 U.S. 374 (1978) (right to marry). The Court has further stated: "If the right of privacy means anything, it is the right of the individual, married or single, to be free from unwarranted governmental intrusion into matters so fundamentally affecting a person as the decision whether to bear or beget a child." Eisenstadt v. Baird, 405 U.S. 438,453 (1972) (emphasis in original).

76. Carey, 431 U.S. at 688.

77. Id. Similarly, the Court held that a statute that placed restrictions on the right of individuals obligated to pay child support to marry was unconstitutional in that it "significantly" interfered with the right to marry, part of the "fundamental 'right of privacy' implicit in the Fourteenth Amendment's Due Process Clause." Zablocki v. Redhail, 434 U.S. 374, 383-84 (1978). In addition to holding that the state may not prohibit abortion, Roe v. Wade, 410 U.S. 113 (1973), the Court has also held unconstitutional statutes that infringe on a woman's right to choose to abort. See, e.g., Doe v. Bolton, 410 U.S. 179, 195-200 (1973) (Court struck down as "unduly restrictive" statutory requirements that all abortions be performed in accredited hospitals, be approved by committee of at least three members of hospital's staff and two physicians in addition to woman's physician, and be restricted to state residents); Planned Parenthood v. Danforth, 428 U.S. 52, 67-71, 75-79 (1976) (Court held unconstitutional statutory requirement of spousal consent for abortions and statutory prohibition of saline amniocentesis as method of abortion); Akron Center for Reproductive Health v. City of Akron, 462 U.S. 416 (1983) (Court held unconstitutional various provisions of abortion statute, including mandatory twenty-four hour waiting period before performance of any abortion, requirement that post first trimester abortions be performed in hospital, "informed consent" provision, and requirement concerning disposition of remains of abortions).

78. 414 U.S. 632 (1974).

79. Id. at $639-40$. 
means of enforcement. In Griswold $v$. Connecticut, for example, the Court held that a statute prohibiting the use of contraceptives violated the right to privacy in part because the state intrusions necessary for enforcement would be tremendous. ${ }^{80}$ Similarly, in order to enforce fetal rights or state regulations dictating behavior during pregnancy, the state would necessarily intrude in the most private areas of a woman's life. The state would have to police what a woman ate and drank, the types of physical activity in which she engaged, with whom and how often she had sexual intercourse, and where she worked-to name only a few areas of regulation. The enforcement of direct state regulation of pregnant women's actions, as in cases involving court-ordered medical treatment against the pregnant woman's wishes, would require the state forcibly to take the pregnant woman into physical custody in order to impose the ordered action.

In order to withstand the strict scrutiny necessitated by the infringements on women's constitutional rights to liberty and privacy, any state recognition of fetuses that operates to the detriment of women must be necessary to protect a compelling state interest. ${ }^{81}$ That is, not only must the law promote a compelling state interest, but it must also be narrowly tailored to do so in the manner that is least intrusive on protected rights. Laws that attempt to regulate the actions of pregnant women by creating fetal rights clearly do not survive this standard. ${ }^{82}$ Rather, they allow pre-

80. The Court wrote, "Would we allow the police to search the sacred precincts of marital bedrooms for telltale signs of the use of contraceptives? The very idea is repulsive to the notions of privacy surrounding the marriage relationship." 381 U.S. 479, 485-86 (1965).

81. When a law infringes upon a fundamental constitutional right or involves a suspect classification, the courts must apply strict scrutiny in evaluating its constitutional validity. San Antonio Indep. School Dist. v. Rodriguez, 411 U.S. 1, 16 (1973). The law must be narrowly tailored so as not to infringe unduly on the protected freedom, and the means selected must be the least intrusive available:

[S]trict scrutiny means that the State's system is not entitled to the usual presumption of valid-

ity, that the State rather than the complainants must carry a 'heavy burden of justification,'

that the State must demonstrate that [the law] has been structured with 'precision,' and is

'tailored' narrowly to serve legitimate objectives and that it has selected the 'less drastic means'

for effectuating its objectives.

Id. at 16-17; see also Shelton v. Tucker, 364 U.S. 479, 488 (1960) ("[E]ven though the governmental purpose be legitimate and substantial, that purpose cannot be pursued by means that broadly stifle fundamental personal liberties when the end can be more narrowly achieved."); Cantwell v. Connecticut, 310 U.S. 296, 304 (1940) ("In every case the power to regulate must be so exercised as not, in attaining a permissible end, unduly to infringe the protected freedom.").

82. Those advocating state regulation of pregnant women's actions might argue that the "potentiality for life" of the viable fetus qualifies as a compelling state interest that justifies giving the fetus rights that can be used against the pregnant woman in nonabortion contexts. The "logical and biological justifications" for drawing the line at viability discussed by the Court in Roe, however, are simply nonexistent in the fetal rights context. As discussed above, see supra text accompanying notes 55-56, the concerns in nonabortion contexts differ significantly from those present in the abortion context. When restricting access to abortions after viability, the state seeks to prevent the destruction of a fetus that, by definition, has the potential to live outside of the woman's womb. In the nonabortion context, the state seeks to create fetal rights out of a concern for the health of the fetus, and, where those rights are contingent upon live birth, the health of its future citizens. It seeks to further this interest by 
cisely the type of unnecessarily sweeping state intrusion upon basic individual rights that the Constitution prohibits. To deprive women of their right to control their actions during pregnancy is to deprive women of their legal personhood.

\section{Fetal Rights and Sex Equality}

Existing liberty and privacy doctrine recognizes the threat to pregnant women's autonomy posed by fetal rights laws. Yet existing doctrine does not describe the full extent of the injury involved, for it does not identify the sex-specific nature of that injury. Only women can suffer the great intrusions of such laws, for only women have the ability to bear children. Fetal rights laws would not only infringe on constitutionally protected liberty and privacy rights of individual women, they would also serve to disadvantage women as women by further stigmatizing and penalizing them on the basis of the very characteristic that historically has been used to perpetuate a system of sex inequality.

The equal protection clause of the Fourteenth Amendment protects individuals from discrimination that is based on their membership in a disadvantaged group. It is now well established that the equal protection

substituting its judgment for that of the pregnant woman concerning how she should behave during pregnancy and by preventing her from acting in ways that it views as posing unacceptable risks to the health of the fetus. As this Note has argued, this asserted state interest fails to qualify as compelling, and, in fact, is clearly illegitimate. See Shapiro v. Thompson, 394 U.S. 618, 631 (1969) (invalidating restriction of constitutional right to travel, stating, "[i]f a law has "no other purpose . . than to chill the assertion of constitutional rights by penalizing those who choose to exercise them then it [is] patently unconstitutional" ") (quoting United States v. Jackson, 390 U.S. 570, 581 (1968)).

Furthermore, viability is a meaningless distinction in the fetal rights context because the state's interest in the health of its future citizens is equally strong throughout pregnancy. Drawing a line at the third trimester would be an ineffective means of preventing unintentional harm to the fetus resulting from the behavior of the pregnant woman. In fact, the woman's actions have the greatest impact on the development of the fetus during the first trimester of pregnancy, during most of which time she typically does not know that she is pregnant. Trying to enforce the viability distinction in cases of prenatal injury due to the woman's behavior during pregnancy also presents huge problems of proof, as it would require identifying a specific point at which a woman's actions harmed the fetus. Thus, viability is an arbitrary point at which to begin restricting the woman's actions in these contexts.

In fact, application of the viability requirement in nonabortion contexts has actually hindered the courts from protecting the ability of born children to recover damages from third parties for injuries inflicted prenatally. When recognizing fetal rights contingent upon live birth and against third parties, courts sometimes feel constrained by the viability distinction drawn in Roe and by potential conceptual conflicts with the abortion right. See, e.g., supra notes $48-50$ and accompanying text. Continuing to view this legal recognition as protecting the interests of born children and their parents would eliminate those constraints. For example, allowing recovery for prenatal injuries against third parties as compensation for real harm that the born child presently suffers reveals that the injury is identical whether it was inflicted before or after the attainment of viability, thus permitting more complete protection. Recognizing this, many courts have abandoned the viability distinction in cases involving prenatal injuries, see PROSSER \& KEETON, supra note 8, at 369, and one court has allowed a child to sue a pharmaceutical company for personal injuries resulting from damage to its mother's chromosomes that occured prior to conception. Jorgensen v. Meade-Johnson Labs., 483 F.2d 237 (10th Cir. 1973). 
clause protects women from discrimination on the basis of sex. ${ }^{83}$ Current doctrine, however, offers women no protection against discrimination that is based on real biological differences between women and men, and in fact denies that such discrimination is sex-based. Women are granted equal protection of the laws only to the extent that they are "similarly situated" to men. In the contexts of both equal protection and Title VII challenges, the Court has stated that discrimination on the basis of pregnancy does not discriminate against women, but rationally discriminates between pregnant people and nonpregnant people. ${ }^{84}$ Through its passage of the Pregnancy Discrimination Act, Congress immediately rejected the Court's position for purposes of employment discrimination under Title VII. ${ }^{88}$ This Act amended Title VII's definition of sex discrimination to include pregnancy-related discrimination. Yet the Court has not to date reevaluated its holding that pregnancy discrimination is not sex discrimination for purposes of equal protection analysis. Unless the Court reverses itself, it is likely to uphold, without even employing heightened scrutiny, any unequal treatment of the sexes that is predicated on the reproductive difference, regardless of the magnitude of the harm imposed on women.

By blindly applying a requirement that the groups being compared be similarly situated, and by viewing reproductive differences as a permissible basis for differential treatment, the Court has substituted misguided formalism for what should be the true goal of equal protection analysis in cases of alleged discrimination - that is, to prevent the state from systematically disadvantaging on the basis of an immutable characteristic a class of people who historically have been disadvantaged on the basis of that

83. Laws that discriminate on the basis of sex are currently subject to "intermediate scrutiny," a standard that requires that "classifications by gender must serve important governmental objectives and must be substantially related to the achievement of those objectives." Craig v. Boren, 429 U.S. 190, 197 (1976). The Court has never articulated clearly why "strict scrutiny," the more stringent standard used for race, should not also apply for sex. In fact, in an earlier decision, four Justices had ruled that sex should be regarded as a suspect class and strict scrutiny applied. Frontiero v. Richardson, 411 U.S. 677, 682-88 (1973) (plurality opinion). In a recent decision, the Court invalidated a sex-based classification as not surviving intermediate scrutiny, and stated "we need not decide whether classifications based upon gender are inherently suspect." Mississippi Univ. for Women v. Hogan, 458 U.S. 718,724 n.9 (1982).

84. Geduldig v. Aiello, 417 U.S. 484 (1974) (equal protection); General Elec. v. Gilbert, 429 U.S. 125 (1976) (Title VII).

85. Pub. L. No. 95-555, § 1, 92 Stat. 2076 (codified at 42 U.S.C. $\S 2000$ e(k) (1982)). The Pregnancy Discrimination Act reads in relevant part:

The terms 'because of sex' or 'on the basis of sex' include, but are not limited to, because of or on the basis of pregnancy, childbirth, or related medical conditions; and women affected by pregnancy, childbirth, or related medical conditions shall be treated the same for all employment-related purposes, including receipt of benefits under fringe benefit programs, as other persons not so affected but similar in their ability or inability to work . . . .

While Gilbert was effectively overruled by the Pregnancy Discrimination Act, Geduldig remains controlling for purposes of equal protection analysis. 
characteristic. $^{86}$ In the race context, the standard for equal protection analysis that requires that similarly situated people be treated the same generally functions well as a proxy for the goal of avoiding the real harm of detrimental discriminatory treatment under the law. In most cases, skin color is irrelevant and attempts to classify according to race are properly suspect. $^{87}$

The ability to bear children is to sex discrimination what dark skin is to race discrimination. It is the immutable characteristic that distinguishes the disadvantaged from the advantaged and which historically has been used to justify the subordination of the disadvantaged. Yet the similarly situated model designed for race is simply inappropriate in cases of sex discrimination. ${ }^{88}$ In the case of sex, it is a dissimilar situation ${ }^{88}$ that has been used to erect and justify a system of male dominance. By dismissing claims of sex discrimination on the grounds that the sexes are differently situated in matters of reproduction, the Court rationalizes differential treatment of the sexes as legitimate and as merely "reflecting" the fact of biological difference. In fact, it is society's disvaluing of that difference, and not its mere existence, that has created the existing inequalities between the sexes. ${ }^{90}$

86. Several leading scholars have written persuasively in support of such an anti-caste approach. See Black, The Lawfulness of the Segregation Decisions, 69 YAl. L.J. 421 (1960); Dimond, The Anti-Cast Principle-Toward $\dot{a}$ Constitutional Standard for Review of Race Cases, 30 WAYNE L Rev. 1 (1983); Fiss, Groups and the Equal Protection Clause, 5 PHil. \& PuB. Aff. 107 (1976).

87. There may be some relatively rare instances where blacks and whites are not similarly situated in some sense, as, for example, when there exist statistical differences between the races that might be useful for determining insurance rates. Race remains an impermissible basis for classification in these cases, despite its relevance, as a result of our larger commitment to securing equality. In cases of affirmative action, on the other hand, differential treatment on the basis of an otherwise forbidden classification is permitted because its object is to reduce the targeted harm.

88. For insightful discussions of the shortcomings of current equal protection analysis as applied to sex, see Law, Rethinking Sex and the Constitution, 132 U. PA. L. REv. 955 (1984); C. MAcKinnon, The Sexual Harassment of Working Women: A Case of Sex Discrimination 101-41 (1979).

89. The reproductive difference between the sexes is occasionally of great relevance and legitimately legally cognizable. Women's ability to bear children is essential to the survival of humankind and should be accomodated and rewarded. It is only when that ability is used to disadvantage women that it is an impermissible basis for legal action. See Law, supra note 88, at 1007-40; Note, Employment Equality Under the Pregnancy Discrimination Act of 1978, 94 YALE L.J. 929, 929-30 (1985) (arguing Title VII as amended by Pregnancy Discrimination Act requires "not only comparable treatment [for female employees], but that measure of institutional accomodation necessary to bear children without forfeiture of employment opportunites").

90. Although the reproductive difference is the one significant biological difference between the sexes, as is frequently observed, "women's reproductive situation is never the result of biology alone, but of biology mediated by social and cultural organization." $R$. PETCHESKy, ABortion AND Woman's Ghoice 5 (1984). See also S. DE Beauvoir, The Second Sex 3-41 (1974).

Not only does the Court refuse to recognize equality claims based on reproductive difference, it also continues to confuse socially-created, sex-based stereotypes with natural, biological differences between the sexes. See, e.g., Michael M. v. Superior Court, 450 U.S. 464 (1981) (upholding California's statutory rape law making it criminal for any man, regardless of age, to have sex with minor woman, but imposing no penalties on women for having sex with minor men); Parham v. Hughes, 441 U.S. 347 (1979) (upholding statute that permitted unmarried mothers to bring tort claims for wrong- 


\section{Women's Rights/Fetal Rights}

State and social regulations concerning reproductive differences have served to create and reinforce separate and unequal sex-segregated spheres in the United States. Women's ability to bear children has been used to systematically disadvantage women by defining their "proper" role in terms of that ability. Social determinations concerning the reproductive difference underlie our present patriarchal society in which men and male norms have dominated the "public" sphere, the locus of political and economic power, while women have been relegated to the "private" sphere, where they provide the socially-necessary but socially-unrewarded work of care for children and home. ${ }^{91}$ Conformity to prescribed sex roles has been accomplished through the imposition of economic, social and legal constraints, such as protectionist legislation. For example, in the past the Court has upheld restrictions placed on the hours women could work, citing a "public interest" in protecting the well-being of the fetus. ${ }^{92}$ The Court has also upheld the exclusion of women from the legal profession, citing the "wide difference in the respective spheres and destinies of men

ful death of their children but denied unmarried fathers the right to bring such claims); see also Law, supra note 88, at 987-1002. Law writes that these "cases illustrate more than the Court's consistent confusion of biology with the social consequences of biology. They also demonstate the breakdown in current sex equality doctrine that occurs when the Court reviews a classification that, in its view, is based upon biological differences." Id. at 1001.

The Court also trivializes the impact on women's lives of laws that use women's biology in ways that disadvantage them. In failing to recognize the equality interests raised by the social treatment of the reproductive difference, the Court acts as if "women need only be treated as persons when they are not engaged in their childbearing function." Scales, Towards a Feminist Jurisprudence, 56 INDIANA L.J. 375, 398 (1981).

By so doing, the Court ignores the effects of centuries of such disadvantaging. Women cannot be separated thus from their reproductive capacity, and laws that disadvantage women on the basis of that difference inevitably will affect all aspects of their lives. Because pregnancies occur in women's bodies, the continued possibility of an 'unwanted' pregnancy affects women in a very specific sense, not only as potential bearers of fetuses but also in their capacity to enjoy sexuality and maintain health. A woman's right to decide on abortion, and, it follows, on childbearing issues when her health and sexual self-determination are at stake is 'nearly allied to her right to be.' Reproduction affects women as women; it transcends class divisions and penetrates everything: work, political and community involvements, sexuality, creativity, and
dreams.

R. Petchesky, supra at 5.

91. See generally Z. Eisenstein, Feminism and Sexual Equality: Crisis in Liberal AMERICA 87-113 (1984).

92. In Muller $v$. Oregon, the Court upheld a statute that restricted the hours women could work but did not place similar restrictions on men. The Court used as a rationale for this differential and clearly disadvantageous treatment a "public interest" in protecting the well-being of the fetus through preserving the health of women:

That woman's physical structure and the performance of maternal functions place her at a disadvantage in the struggle for subsistence is obvious. This is especially true when the burdens of motherhood are upon her. Even when they are not, by abundant testimony of the medical fraternity continuance for a long time on her feet at work, repeating this from day to day, tends to injurious effects upon the body, and as healthy mothers are essential to vigorous offspring, the physical well- being of woman becomes an object of public interest and care in order to preserve the strength and vigor of the race.

208 U.S. 412, 421 (1908). 
and women." The "burdens necessarily borne by women for the preservation of the race" were even used as an excuse to justify exempting women from paying poll taxes if they "chose" not to vote, thus discouraging women from participating in the political process. ${ }^{94}$ More recently, the Court upheld a statute exempting all women from compulsory jury duty in recognition of women's "special responsibilities" in the home.95

The social and legal treatment accorded women's reproductive capacity will inevitably shape the status of women in the United States. Despite the Court's pronouncements to the contrary, laws that disadvantage people on the basis of pregnancy disadvantage only women. Given that women's ability to bear children historically has served as the primary justification for denying women equality, courts should scrutinize with particular care laws that deal with matters of reproduction to ensure that they do not operate to the detriment of women. Equal protection doctrine should incorporate the approach advocated by Professor Sylvia Law. Law proposes that "laws governing reproductive biology be scrutinized by courts to ensure that (1) the law has no significant impact in perpetuating either the oppression of women or culturally imposed sex-role constraints on individual freedom or (2) if the law has this impact, it is justified as the best means of serving a compelling state purpose." ${ }^{298}$

Granting rights to fetuses in a manner that conflicts with women's autonomy reinforces the tradition of disadvantaging women on the basis of their reproductive capability. By subjecting women's decisions and actions during pregnancy to judicial review, the state simultaneously questions women's abilities and seizes women's rights to make decisions essential to

93. In Bradwell v. Illinois, the Court upheld a decision by the Supreme Court of Illinois to prohibit women from practicing law, relying on the "natural" differences between the sexes:

[T] The civil law, as well as nature herself, has always recognized a wide difference in the respective spheres and destinies of man and woman . . . The constitution of the family organization, which is founded in the divine ordinance, as well as in the nature of things, indicates the domestic sphere as that which properly belongs to the domain and functions of womanhood .... [T] he paramount destiny and mission of women are to fulfill the noble and benign offices of wife and mother. This is the law of the Greator. And the rules of civil society must be adapted to the general constitution of things.

83 U.S. 130, 141-42 (1873) (Bradley, J., concurring).

94. "In view of burdens necessarily borne by them for the preservation of the race, the State reasonably may exempt [women] from poll taxes." Breedlove v. Suttles, 302 U.S. 277, 282 (1937).

95. Hoyt v. Florida, 368 U.S 57, 62 (1961). The Florida statute in question exempted all women from jury duty unless they registered with the clerk a desire to be placed on the jury list. This exclusion resulted in only 220 women volunteering for jury duty in a county with approximately 46,000 registered female voters in the year 1957. Id. at 64. Despite this great discrepancy, the Court, noting that "woman is still regarded as the center of home and family life," held that the state constitutionally could permit women to determine if jury duty was consistent with their own "special responsibilities." Id. at 62.

96. Law, supra note 88, at 1008-09. Law says further: "Given how central state regulation of biology has been to the subjugation of women, the normal presumption of constitutionality is inappropriate and the state should bear the burden of justifying its rule in relation to either proposition." Id. at 1009. 
their very personhood. The rationale behind using fetal rights laws to control the actions of women during pregnancy is strikingly similar to that used in the past to exclude women from the paid labor force and to confine them to the "private" sphere. Fetal rights could be used to restrict pregnant women's autonomy in both their personal and professional lives, in decisions ranging from nutrition to employment, in ways far surpassing any regulation of the actions of competent adult men. The state would thus define women in terms of their childbearing capacity, valuing the reproductive difference between women and men in such a way as to render it impossible for women to participate as full members of society. ${ }^{97}$ In light of the great threat to women's right to equality posed by legal recognition of the fetus, the state should bear the burden of ensuring that any law granting fetal rights does not disadvantage women or in any way infringe on the autonomy of pregnant women.

97. In discussing the potential effects of an amendment to the U.S. Constitution that would label the fetus a legal person under the Constitution, one commentator has noted:

[Women] might be required to lead less active life-styles in order to preserve the life of a conceptus (or possible conceptus). The interests of the conceptus will often diverge from those of the woman in such matters. From the standpoint of the conceptus, a passive carrier who exposes it to the minimum risk of miscarriage or prenatal injury is preferred. She should not smoke, drink, or use any drugs with possible adverse effects on the conceptus. Skiing, working in hazardous environments, flying, and riding in automobiles might be prohibited for such women in order to minimize possible adverse effects on the conceptus. Indeed, the Victorian regime for upper-class pregnant women that minimizes activities either inside or outside the home might be ideal.

Westfall, supra note 27 , at 111 . Another commentator noted that, in addition to the above, "maternal discretion to . . . engage in immoderate exercise or sexual intercourse . . . or reside at high altitudes for a prolonged period might be limited." Parness, supra note 27 , at 500 . Such restrictions might not be limited to pregnant women, but might be extended to all women as "potentially pregnant": "Restricting the activities of potentially pregnant women might similarly be justified on the ground that such classification is necessary to protect the conceptus during the period between conception and proof of pregnancy." Westfall, supra note 27, at 111 . 
